\title{
Risk Factors of Otitis Media with Effusion in Children
}

\author{
Essam A. Abo el-Magd1, Yousseria Elsayed Yousef², Osama M. El-Asheerr³, \\ Karema M. Sobhy ${ }^{4}$ \\ ${ }^{1}$ Departments of Otorhinolaryngology, Faculty of Medicine, Aswan University, Aswan, Egypt \\ ${ }^{2}$ Pediatric Nursing, Faculty of Nursing, Sohag University, Sohag, Egypt \\ ${ }^{3}$ Pediatrics, Faculty of Medicine, Assiut University, Assiut, Egypt \\ ${ }^{4}$ Public Health, Faculty of Medicine, Aswan University, Aswan, Egypt \\ Email: esamali801@yahoo.com
}

Received 28 March 2015; accepted 24 July 2015; published 27 July 2015

Copyright (C) 2015 by authors and Scientific Research Publishing Inc.

This work is licensed under the Creative Commons Attribution International License (CC BY).

http://creativecommons.org/licenses/by/4.0/

(c) (i) Open Access

\begin{abstract}
The aim of this study is to detect the risk factors associated with otitis media with effusion (OME) among children with age ranged from 6 months to 2 years. Materials and Methods: it is a crosssectional study 500 children were selected from Assiut University Hospital clinics through multistaged randomized sampling. Parents of these children were interviewed with a structured questionnaire. Clinical examination, including otoscopic examination and tympanometry was performed for each child. Results: There was no statistical significant relationship between OME and gender, age, mother job. There is statistical significant relationship between OME and breast feeding, using pacifier, mother education, sibling of children and exposure to passive smoking. Conclusion: There are multiple risk factors associated with OME in children between 6 months to 2 years of age.
\end{abstract}

\section{Keywords}

Otitis Media with Effusion, Risk Factors

\section{Introduction}

Otitis media with effusion (OME) is a middle ear disease characterized by presence of serous or mucoid effusion in the middle ear without any signs of acute infection1. This problem occurred because of Eustachian tube dysfunction as well as other problems in the middle ear ventilation. Twenty to fifty percent of children aged 3 - 10 years' experience otitis media with effusion at least once in this period [1] [2]. 
Vague presentations of otitis media in early stages and coincidence of the disease with the time of learning and speaking of the child cause many problems such as stuttering, delay of speaking, indifference of children at school, and educational problems [3]. Various risk factors are implicated, such as sex, race, premature delivery, passive smoking, allergy, asthma, family size, bottle feeding, socioeconomic status, cleft palate adenoid hypertrophy, which have been studied and are still controversial [4]-[7].

Passive smoking can increase the adherence of bacteria to the respiratory epithelium, depress local immune function and decrease mucociliary action, and thus may be a risk factor for the development of OM [8] [9].

\section{Materials and Methods}

In this cross-sectional study 500 children whose age ranged from 6 months to 2 years were selected from Aswan University Hospital Clinics through multi-stage randomized sampling in the period between June 2013 and December 2014 after approval from Aswan Faculty of Medicine ethics committee. Informed consent was obtained from the parents who agreed to be interviewed and have their children examined.

Children were considered to have OME in case of:

- Lack of cerumen in their ears

- Intact tympanic membrane

- Type B tympanogram

Retraction of tympanic membrane/or disappearance of cone of light/or presence of air-fluid level in examination.

There were healthy children matched to the case group as the control subjects. They collected information on smoking behavior of parents and other household members. Mothers were asked: "if father's child was smoke?" if he still smoking?” and "Did he/she smoke inside the house, outside only or both?” If the baby's father was part of the family unit, we asked the same questions about the baby's mother.

Lastly, we asked the mother or guardian whether anybody else smoked inside the house. An answer of "yes" to any of these questions was taken to indicate ETS exposure. Information was also collected about feeding practices, parent's education and employment, family history of allergy or atopy, and number, age, and childcare or school attendance of other children in the household. The number of adults and children living in the house as well as the number of rooms in the house were documented to obtain a measure of crowding (number of people/ room). Research assistants performed further routine follow-up on study participants at ages 6 - 8 weeks, and 4, 6, 12, 18 and 24 months, when they again enquired about feeding practices and whether the study participant was attending childcare.

At these follow-up visits, we also asked the child's mother or guardian whether they smoked, and whether anybody smoked inside the house. However, as preliminary analysis indicated little change from responses at first interview and, in view of potential bias towards children remaining in the study, analyses were based on the first interview.

We scheduled three routine clinical examinations by an ear, nose and throat (ENT) specialist: before the age of 6 months, at 6 - 11 months and at 12 - 24 months. A clinical diagnosis was established by otoscopy, pneumatic otoscopy and tympanometry at 6 months, 12 months and at 24, and was based on national clinical guideline and approved by the local Ethics committee.

\section{Statistical Analysis}

The collected data were computerized and analyzed by using the proper statistical programs such as "SPSS" ver. 16". Data expressed as mean, SD and number, percentage. Using $t$ test to determine significant for numeric variable Using Chi. square to determine significant for non-parametric variable. The difference was considered statistically significant when P-value $\leq 0.05 \%$.

\section{Result}

A total of 250 children were examined. The examined group compared with 250 children of control group. Mean age of cases was $18.16 \pm 11.9$ months while it was $19.55 \pm 9.10$ months for controls. $61.6 \%$ of cases and $66 \%$ of controls were females, with no significant difference between cases and controls ( $P>0.05)$. 94\% of cases and $92 \%$ of controls were Urban with no significant difference $(P>0.05)$. On the other hand, for the higher 
percentage $28 \%$ of cases and $58 \%$ of controls, their mothers completed university education with significant statistical difference between them $\mathrm{P}=0.000$. For more than half, $68.8 \%$ of cases and $74.8 \%$ of controls, their mothers worked with no statistical significant difference between them $(P>0.05)$. There was a high significant difference between cases $45.6 \%$ versus $34 \%$ of controls had family history of second sibling of children $\mathrm{P}=0.00$. The majority $92.4 \%$ of cases versus $83.6 \%$ of controls the number of children per room were 1 - 2 child with high statistical significant difference between them $\mathrm{P}=0.02$ (Table 1 ). There was a highly statistically significant relationship between OME and breast feeding, use of pacifier, father smoke, exposure to smoke (Table 2) (Figure 1).

Table 1. Sociodemographic characteristics among study participants and their controls at Assuit University Hospital, 2014.

\begin{tabular}{|c|c|c|c|c|c|}
\hline \multirow{2}{*}{ Variable } & \multicolumn{2}{|c|}{ Cases (No. 250) } & \multicolumn{2}{|c|}{ Control (No. 250) } & \multirow{2}{*}{ Significant Tests } \\
\hline & No. & $\%$ & No. & $\%$ & \\
\hline \multicolumn{6}{|c|}{ 1-Age "months" } \\
\hline Mean \pm SD & \multicolumn{2}{|c|}{$18.16 \pm 11.19$} & \multicolumn{2}{|c|}{$19.55 \pm 9.10$} & $\begin{array}{c}\text { T-test }=2.54 \\
\mathrm{P}=0.128 \\
\text { n.s }\end{array}$ \\
\hline \multicolumn{6}{|c|}{ 2-Sex: } \\
\hline $\begin{array}{c}\text { Male } \\
\text { Female }\end{array}$ & 154 & $\begin{array}{l}38.4 \\
61.6\end{array}$ & $\begin{array}{r}85 \\
165\end{array}$ & $\begin{array}{l}34.0 \\
66.0\end{array}$ & $\begin{array}{l}x^{2}=1.048 \\
\mathrm{P}=0.176\end{array}$ \\
\hline \multicolumn{6}{|c|}{ 3-Residence: } \\
\hline $\begin{array}{l}\text { Rural } \\
\text { Urban }\end{array}$ & $\begin{array}{r}15 \\
235\end{array}$ & $\begin{array}{c}6.0 \\
94.0\end{array}$ & $\begin{array}{r}20 \\
230\end{array}$ & $\begin{array}{c}8.0 \\
92.0\end{array}$ & $\begin{aligned} x^{2} & =0.768 \\
P & =0.242\end{aligned}$ \\
\hline \multicolumn{6}{|c|}{ 4-Level of education of mother } \\
\hline Illiterate & 29 & 11.6 & 21 & 8.4 & \multirow{5}{*}{$\begin{array}{c}x^{2}=51.965 \\
P=0.000\end{array}$} \\
\hline Read and write & 38 & 15.2 & 22 & 8.8 & \\
\hline Primary education & 58 & 23.2 & 20 & 8.0 & \\
\hline Secondary education & 55 & 22.0 & 42 & 16.8 & \\
\hline University & 70 & 28.0 & 145 & 58.0 & \\
\hline \multicolumn{6}{|c|}{ 5-Mother Job } \\
\hline Work & 172 & 68.8 & 187 & 74.8 & $x^{2}=2.222$ \\
\hline House wife & 78 & 31.2 & 63 & 25.2 & $P=0.082$ \\
\hline \multicolumn{6}{|c|}{ 6-Sibling of children } \\
\hline First & 58 & 23.2 & 63 & 25.2 & \multirow{5}{*}{$\begin{aligned} x^{2} & =32.139 \\
P & =0.000\end{aligned}$} \\
\hline Second & 114 & 45.6 & 85 & 34.0 & \\
\hline Third & 39 & 15.6 & 61 & 24.4 & \\
\hline Fourth & 20 & 8.0 & 40 & 16.0 & \\
\hline Fifth & 19 & 7.6 & 1 & 0.4 & \\
\hline \multicolumn{6}{|c|}{ 7-No. of room } \\
\hline $1-2$ rooms & 231 & 92.4 & 209 & 83.6 & $x^{2}=9.167$ \\
\hline $3-4$ rooms & 19 & 7.6 & 41 & 16.4 & $\mathrm{P}=0.002$ \\
\hline
\end{tabular}




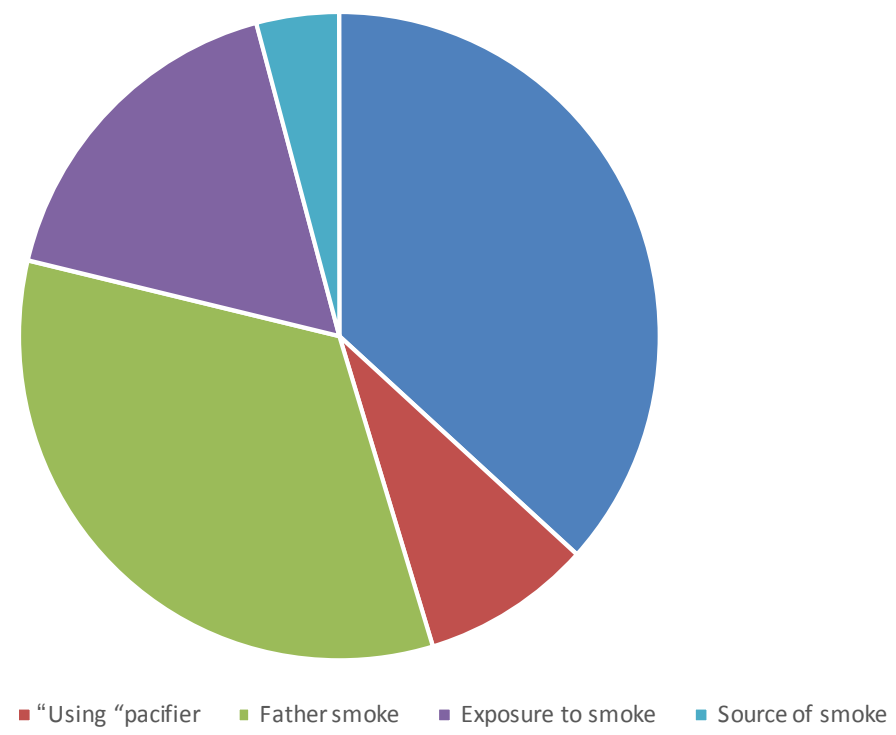

Figure 1. Pie chart for percentage analysis of risk factors among study participants attending Assuit University hospital, 2012.

Table 2. Risk factors among study participants and their controls at Assuit University Hospital, 2014.

\begin{tabular}{|c|c|c|c|c|c|}
\hline \multirow{2}{*}{ Variable } & \multicolumn{2}{|c|}{ Cases (No. 250) } & \multicolumn{2}{|c|}{ Control (No. 250) } & \multirow{2}{*}{ Significant Tests } \\
\hline & No. & $\%$ & No. & $\%$ & \\
\hline \multicolumn{6}{|c|}{ 1-Breast Feeding: } \\
\hline Yes & 168 & 67.2 & 212 & 84.8 & \multirow{2}{*}{$\begin{array}{c}x^{2}=21.228 \\
P=0.000\end{array}$} \\
\hline No & 82 & 32.8 & 38 & 15.2 & \\
\hline \multicolumn{6}{|c|}{ 2-Using “pacifier”: } \\
\hline Yes & 39 & 15.6 & 21 & 8.4 & \multirow{2}{*}{$\begin{aligned} x^{2} & =6.136 \\
P & =0.009\end{aligned}$} \\
\hline No & 211 & 84.4 & 229 & 91.6 & \\
\hline \multicolumn{6}{|c|}{ 3-Father smoke: } \\
\hline Yes & 153 & 61.2 & 106 & 42.4 & \multirow{2}{*}{$\begin{array}{c}x^{2}=17.695 \\
P=0.000\end{array}$} \\
\hline No & 97 & 38.8 & 144 & 57.6 & \\
\hline \multicolumn{6}{|c|}{ 4-Exposure to smoke: } \\
\hline Yes & 78 & 31.2 & 42 & 16.8 & $x^{2}=14.211$ \\
\hline No & 172 & 68.8 & 208 & 83.2 & $\mathrm{P}=0.000$ \\
\hline \multicolumn{6}{|c|}{ 5-Source of smoke: } \\
\hline Yes & 19 & 7.6 & 1 & 0.4 & \multirow{2}{*}{$\begin{array}{c}x^{2}=16.875 \\
P=0.000\end{array}$} \\
\hline No & 231 & 92.4 & 249 & 99.6 & \\
\hline
\end{tabular}

\section{Discussion}

In the literature, the range of prevalence of OME is wide as the population studied, the countries, environmental factors and climatic factors were different [10]. In our study we did not find any significant difference in the incidence of OME between male and female. Other studies showed higher incidence in male [11]-[13], owing to higher incidence of infectious disease in male. In the same with our results Gultekin et al. [14] and Sassen et al. [15] showed that higher number of siblings in family increases the risk of OME. Various studies done in the past support the protective role of breast feeding and development of OME [12] [13] [16] [17] but other studies did 
not establish a significant relationship between the two [14] [15] [18] [19]. Various studies with different designs relating to middle ear disease among young children have a point of consistence in suggesting a modest increase in the risk associated with parental smoking [1] [2] [17].

Hinton et al. demonstrated that parental smoking is an influential factor in OME among the children. They require more ventilation tube insertion for OME treatment, comparing with other patients with the same age [20].

This indicates the resistance of OME to suitable therapeutic modalities. Green et al. showed the increased risk of OME in case of parental smoking especially with maternal smoking during pregnancy [21].

Moreover, Etzel et al. have presented cigarette smoking as an effective factor in extension of the disease period and increasing the frequency of the disease attacks at shorter intervals [22]. Their results are similar to our findings on parental smoking, since both studies indicate increased risk of OME among children with smoker parents. Furthermore, a direct relation exists between pack-years cigarette smoking of parents and the prevalence of the disease. Blackley and Blackley [7], and few others [15] [16] [23] [24] deny any relationship between passive smoking and development of OME. Other studies demonstrated the relationship between the two [24] [25].

Finally, we believe that passive smoking is a preventable cause of otitis media with effusion in children. This seeks further parental attention. The limitations of our study are small number of patients and short period of follow up.

\section{References}

[1] Strachan, D.P. and Cook, D.G. (1998) Health Effect of Passive Smoking. Thorax, 53, 50-56. http://dx.doi.org/10.1136/thx.53.1.50

[2] Hinton, A.E. and Buckiey, G. (1988) Parental Smoking and Middle Ear Effusion in Children. The Journal of Laryngology \& Otology, 102, 992-996. http://dx.doi.org/10.1017/S0022215100107091

[3] Abbas, S., Ali, S. and Mohsen, V. (2002) Parental Smoking and Risk of Otitis Media with Effusion among Children. Tanfos, 1, 25-28.

[4] Alho, O.-P., Oja, H., Koivu, M. and Sorri, M. (1995) Risk Factors for OME in Infancy. Archives of OtolaryngologyHead Neck Surgery, 121, 839-843. http://dx.doi.org/10.1001/archotol.1995.01890080011002

[5] Aydogan, B., Kirgolu, M. and Yilmaz, M. (2004) The Role of Food Allergy in OME. Otolaryngology—Head and Neck Surgery, 130, 747-750. http://dx.doi.org/10.1016/j.otohns.2004.02.003

[6] Bernstein, J.M. (1992) The Role of IgE Mediated Hypersensitivity in Development of OME. Otolaryngologic Clinics of North America, 25, 197-211.

[7] Blakley, B.W. and Blakley, J. (1995) Smoking and Middle Ear Disease: Are they Related? A Review Article. Otolaryngology — Head and Neck Surgery, 112, 441-446. http://dx.doi.org/10.1016/S0194-5998(95)70281-4

[8] Kum-Nji, P., Meloy, L. and Herrod, H.G. (2006) Envirpmental Tobacco Smoke Exposure: Prevelance and Mechanisms of Causation of Infections in Children. Pediatrics, 117, 1745-1754. http://dx.doi.org/10.1542/peds.2005-1886

[9] Arcavi, L. and Benowitz, N.L. (2004) Cigaret Smoking and Infection. Archives of Internal Medicine, 164, $2206-2216$. http://dx.doi.org/10.1001/archinte.164.20.2206

[10] Okur, E., Yildirim, I., Kilic M.A. and Guzelsoy, S. (2004) Prevelance of Otitis Media with Effusion among Primary School Children in Turkey. International Journal of Pediatric Otolaryngology, 68, 557-562. http://dx.doi.org/10.1016/j.ijporl.2003.12.014

[11] Casselbrant, M.L., Brostof, L.M. and Cantekin, E.L. (1985) Otitis Media with Effusion in Preschool Children. The Laryngoscope, 95, 428-436. http://dx.doi.org/10.1288/00005537-198504000-00011

[12] Paradise, J.L, Rockette, H.E. and Calborn, D.K. (1997) Otitis Media in 2253 Infants, Prevelance and Risk Factors. Pediatrics, 99, 318-333. http://dx.doi.org/10.1542/peds.99.3.318

[13] Teele, D., Klein, J. and Rosner, B. (1989) Epidemiology of Otitis Media in Children in Greater Boston: Prospective Study. The Journal of Infectious Diseases, 160, 83-94. http://dx.doi.org/10.1093/infdis/160.1.83

[14] Gultekin, E., Yener, M. and Ozdemir, I. (2010) Prevelance and Risk Factors for Persistent Otitis Media with Effusion in Primary School Children in Turkey. Auris Nasus Larynx, 37, 145-149. http://dx.doi.org/10.1016/j.anl.2009.05.002

[15] Sassen, M., Brand, R. and Grote, J. (1997) Risk Factors for Otitis Media with Effusion in Children 0 to 2 Years of Age. American Journal of Otolaryngology, 18, 324-330. http://dx.doi.org/10.1016/S0196-0709(97)90027-2

[16] Saim, A., Saim, L. and Saim, S. (1997) Prevelance of OME Amongost Pre-School Children in Malasia. International 
Journal of Pediatric Otorhinolaryngology, 41, 21-28. http://dx.doi.org/10.1016/S0165-5876(97)00049-9

[17] Rowe-Jones, J.M. and Brockbank, M.J. (1992) Parental Smoking and Persistant OME in Children. International Journal of Pediatric Otorhinolaryngology, 24, 19-24. http://dx.doi.org/10.1016/0165-5876(92)90062-T

[18] Schaefer, O. (1971) Otitis Media and Bottle Feeding. An Epidemiological Study of Infant Feeding Habits and Incedance of Recurrent Middle Ear Diseases in Canadian Escemos. The Canadian Journal of Public Health, 62, 478-489.

[19] Haresten, G., Kalmo, O. and Kornfalt, R. (1989) Recurrent Acute Otitis Media. Acta Oto-laryngologica, 107, $111-119$. http://dx.doi.org/10.3109/00016488909127487

[20] Hinton, A.E. (1989) Surgery for Otitis Media with Effusion in Children and Its Relationship to Parental Smoking. The Journal of Laryngology Otology, 103, 556-561. http://dx.doi.org/10.1017/S0022215100109326

[21] Green, R.E. and Cooper, N.K. (1991) Passive Smoking and Middle Ear Effusion in Children. Journal of the Royal Army Medical Corps, 137, 31-33. http://dx.doi.org/10.1136/jramc-137-01-07

[22] Etzel, R.A., Pattishall, E.N. and Haley, N.J. (1992) Passive Smoking and Middle Ear Effusion among Children in Day Care. Pediatrics, 90, 228-232.

[23] Rowe, J. and Brockbank, M. (1992) Parental Smoking and Persistent Otitis Media with Effusion in Children. International Journal of Pediatric Otorhinolaryngology, 24, 19-24.

[24] Iversen, M., Birch, L. and Lundqvist, G. (1985) Middle Ear Effusion in Children and the Indoor Environment: An Epidemiological Study. Archives of Environmental Health, 40, 74-79. http://dx.doi.org/10.1080/00039896.1985.10545893

[25] Uhari, M., Mantysaari, K. and Niemela, M. (1996) A Meta-Analysis Review of the Risk Factors for Acute Otitis Media. Clinical Infectious Diseases, 22, 1079-1083. http://dx.doi.org/10.1093/clinids/22.6.1079 